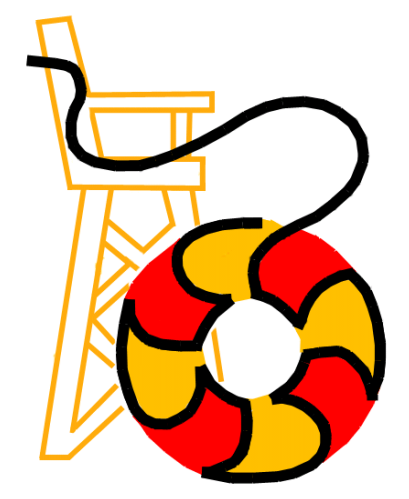

- This publication was written by Regina Fegan and Michael T. Olexa, Food and Resource Economics Department, University of Florida.

- This document, IFAS publication DH0432, was published June 1998, revised May 2003. It is part of The Disaster Handbook, a component of the Comprehensive Disaster Preparedness and Recovery Education Module; General editor: Carol J. Lehtola, Agricultural and Biological Engineering Department, Institute of Food and Agricultural Sciences, University of Florida, Gainesville, Florida 32611.

For information about products and ordering, please visit:

$<$ http://disaster.ifas.ufl.edu>

UF/IFAS Extension publications are available at the EDIS Web site: $<$ http://edis.ifas.ufl.edu>.

- The Institute of Food and Agricultural Sciences is an equal opportunity / affirmative action employer authorized to provide research, educational information, and other services only to individuals and institutions that function without regard to race, color, sex, age, handicap, or national origin. For information on obtaining other extension publications, contact your county Cooperative Extension Service office. Florida Cooperative Extension Service / Institute of Food and

Agricultural Sciences / University of

Florida / Christine Taylor Waddill, Dean.

\section{Individual Assistance Programs from FEMA}

FEMA (Federal Emergency Management Agency) and other federal, state, local, and volunteer agencies offer disaster assistance in several forms:

○ Low-interest loans

- Individual and Family Grant (IFG) program

- Veterans benefits

- Temporary housing assistance

- Tax refunds

- Excise tax relief

- Unemployment benefits

- Free legal counseling

- Crisis counseling

- Getting in touch with family members

- Your Rights

- Florida Emergency Information Line

\section{Low Interest Loans}

Most, but not all, federal assistance is in the form of low interest loans to cover expenses not covered by state or local programs, or private insurance. People who do not qualify for loans may be able to apply for a cash grant.

These agencies offer low interest loans to eligible individuals, farmers and businesses to repair or replace damaged property and personal belongings not covered by insurance.

- Farm Service Agency (FSA) $<$ http://www.fsa.usda.gov/pas/disaster/emloan.htm >

- Small Business Administration (SBA) $<$ http://www.sba.gov/disaster/loans.html>

The Disaster Handbook Individual Assistance Programs from FEMA 


\section{Individual and Family Grant (IFG) Program}

IFG provides cash grants for up to $\$ 14,800$ adjusted annually for inflation. The average grant is in the $\$ 2,000$ to $\$ 4,000$ range. For more information about the IFG programs, visit:

$<$ http://www.fema.gov/about/process/>.

Individuals may be eligible for grants to help recover necessary expenses and serious needs that cannot be met through insurance or other forms of disaster assistance. Examples are housing, personal property, medical, dental, funeral, transportation and required flood insurance premiums incurred as a result of the disaster.

\section{Veterans Benefits}

The Department of Veterans' Affairs provides death benefits, pensions, insurance settlements and adjustments to home mortgages for veterans. For more information, visit:

$$
<\text { http://www.va.gov/>. }
$$

\section{Temporary Housing Assistance}

This program assures that people whose homes are damaged by disaster have a safe place to live until repairs can be completed. This program is designed to provide funds for expenses that are not covered by insurance for homeowners and renters who are legal residents of the United States and are displaced by the disaster.

- Home repair assistance

- Rental assistance

- Mortgage and rental assistance (MRA)

- Referral to other government housing programs may also be provided, if necessary.

For more information about temporary housing assistance, visit:

$<$ http://www.fema.gov/about/process/>

\section{Tax Refunds}

The Internal Revenue Service (IRS) allows certain casualty losses to be deducted on Federal income tax returns for the year of the

The Disaster Handbook Individual Assistance Programs from FEMA 
loss or through an immediate amendment to the previous year's return.

- Internal Revenue Service (IRS) Publication 584 - Casualty, Disaster, and Theft Loss Workbook (Personal-Use Property) $<$ http://www.irs.gov/pub/irs-pdf/p584.pdf>

- Internal Revenue Service (IRS) Publication 2194B - Disaster Losses Kit For Businesses: Help From the IRS $<$ http://www.irs.gov/pub/irs-pdf/p2194b.pdf>

\section{Excise Tax Relief}

Businesses may file claims with the Bureau of Alcohol, Tobacco and Firearms (ATF) for payment of Federal excise taxes paid on alcoholic beverages or tobacco products lost, rendered unmarketable or condemned by a duly authorized official under various circumstances, including where the President has declared a major disaster. For more information, visit:

$<$ http://www.fema.gov/doc/rrr/whendisasterstrikes.doc $>$

\section{Unemployment Benefits}

Unemployment assistance and unemployment insurance benefits may be available through the state unemployment office and supported by the U.S. Department of Labor. For more information, visit:

$<\mathrm{http}$ ://workforcesecurity.doleta.gov/unemploy/disaster.asp $>$

Residents of Florida - If you work or reside in one of the officially declared disaster counties and are now unemployed as a result of the disaster, you may be eligible for Unemployment Compensation Benefits or Disaster Unemployment Assistance. $<$ http://www.floridajobs.org/unemployment/programs/dua.htm>

\section{Free Legal Counseling}

The Young Lawyers Division of the American Bar Association, through an agreement with FEMA, provides free legal advice for low-income individuals regarding cases that will not produce a fee (i.e., those cases where attorneys are paid part of the settlement which is awarded by the court). Cases that may generate a fee are turned over to the local lawyer referral service.

The Disaster Handbook Individual Assistance Programs from FEMA 
Individuals, families and businesses may be eligible for federal assistance if they live, own a business, or work in a county declared a Major Disaster Area, incur sufficient property damage or loss, and, depending on the type of assistance, do not have the insurance or other resources to meet their needs.

\section{Crisis Counseling}

The purpose of the crisis counseling program is to help relieve any grieving, stress, or mental health problems caused or aggravated by the disaster or its aftermath. These short-term services, provided by FEMA as supplemental funds granted to State and local mental health agencies, are only available to eligible survivors of Presidentially-declared major disasters. Those who may require this confidential service should inquire about it while registering for disaster assistance.

Crisis counseling services are also offered by the American Red Cross (<http://www.redcross.org/services/disaster/>), other voluntary agencies, as well as churches and synagogues. Additional mental health information may be found on the U.S. Department of Health and Human Services, Center for Mental Health Services:

$<$ http://www.mentalhealth.org/cmhs/EmergencyServices/ $>$

\section{Getting in Touch with Family Members}

The American Red Cross maintains a database to help you find family. Contact your local American Red Cross chapter. Do not contact the chapter in the disaster area. For more information, visit:

$<\mathrm{http}$ ://www.redcross.org/services/disaster/>

\section{Your Rights}

Each Federal agency that provides Federal financial assistance is responsible for investigating complaints of discrimination in the use of its funds. If you believe that you or others protected by Civil Rights laws have been discriminated against in receiving disaster assistance, you may contact one of FEMA's Equal Rights Officers (ERO) who has the job of ensuring equal access to all FEMA disaster programs. The ERO will attempt to resolve your issues. 


\section{Florida Emergency Information Line}

The Florida Emergency Information Line (FEIL) is a toll-free hotline providing accurate and up-to-date information regarding an emergency or disaster situation impacting the State of Florida. The FEIL hotline is: 1-800-342-3557.

\section{Sources for This Publication}

A Guide to the Disaster Declaration Process and Federal Disaster Assistance

Federal Emergency Management Agency (FEMA). Access on the Web at: $<$ http://www.fema.gov/rrr/dec_guid.shtm $>$.

Individual Assistance

Florida Department of Community Affairs/

Division of Emergency Management. Access on the Web at: $<$ http://www.dca.state.fl.us/brm/Individ\%20Assistance.htm>.

\section{American Red Cross Disaster Services}

Access on the Web at:

$<$ http://www.redcross.org/services/disaster/>.

This publication is designed to provide accurate, current, and authoritative information on the subject. However, since the laws, regulations, administrative rulings, and court decisions on which it is based are subject to constant revision, portions of this publication could become outdated at any time. This publication is distributed with the understanding that the authors are not engaged in rendering legal advice or opinions, and the information contained herein should not be regarded, or relied upon, as a substitute for legal advice or opinion. For these reasons, the utilization of these materials by any person constitutes an agreement to hold harmless the authors, the Institute of Food and Agricultural Sciences and the University of Florida for any liability claims, damages or expenses that may be incurred by any person as a result of reference to or reliance on the information contained in this fact sheet.

The Disaster Handbook Individual Assistance Programs from FEMA 